\title{
A dynamic simulation model of nutrient digestion in the rumen of dairy cows
}

\author{
H. Petruzzi' A. Danfær' and P. Nørgaard ${ }^{2}$ \\ ${ }^{\prime}$ Research Centre Foulum, Danish Institute of Agricultural Sciences, \\ Department of Animal Nutrition and Physiology. \\ PO Box 50, DK-8830 Tjele, Denmark \\ 'The Royal Veterinary and Agricultural University, \\ Department of Animal Science and Animal Health \\ Gronnegaardsvej 3, DK-1870 Frederiksberg C, Denmark
}

(Received 4 Fcbruary 2002; revised version 9 July 2002; accepted 2 August 2002)

\section{ABSTRACT}

A mechanistic model of nutrient digestion in the rumen of dairy cows has been developed to predict rates of nutrient digestion and passage as well as rumen NDF pool sizes at fixed rates of dry matter intake. Different feed fractions according to chemical and physical characteristics are considered. There are 18 rumen state variables representing carbohydrates, nitrogen and microbes in the model. The model is mainly sensitive to the parameters defining rate constants of passage of small particles and digestion rate constant of NDF. For comparative analysis the model has been tested with diets differing widely in intake level and composition. NDF passage and digestibility, NDF pool, total and non-ammonia nitrogen outflow from rumen are well predicted for the whole range of diets used. For some diets, especially those containing maize as a source of starch the predictions of $O M$ and starch digestibility and partition of NAN outflow between dietary and ricrobial $N$ outflow are not satisfactory.

KEY WORDS: dairy cows, rumen, simulation model, digestion, ruminants

\section{INTRODUCTION}

The use of mechanistic modelling for description and integration of different processes occurring in the reticulo-rumen has increased during the last decades. Many rumen models differing in the level of aggregation, complexity of representation of rumen fermentation and the objectives for which they were developed have been published (Mertens and Ellis, 1979; Black et al., 1981; France et al., 1982; Baldwin et al., 1987; Dijkstra et al., 1992; Lescoat and Sauvant, 1995). Some rumen models have been included as a subunit or submodel in a more general mo- 
del of feed intake regulation (Bywater, 1984; Hyer et al., 1991, Illius and Gordon, 1991; Fisher, 1996; Sauvant et al., 1996; Chilibroste et al., 1997) or animal metabolism model (Danfær, 1990; Dijkstra et al., 1996b).

In order to describe the physical and metabolic factors involved in feed intake regulation, the incorporation of a rumen submodel to give a dynamic description of nutrient pools, nutrient digestion and nutrient flow is an inevitable step in the prediction of feed intake in ruminants. In rumen models constructed for this purpose, special attention must be given to both the physical and chemical properties of the feedstuffs that influence rate and pattern of nutrient availability, utilization and passage in the rumen.

Detailed rumen models yielding valuable information have been published (Danfrer, 1990; Dijkstra et al., 1992), but due to the objectives of these models the description of the physical properties of the feed is inadequatc. Baldwin et al. (1987) included particie dynamics in their model with the hypothesis that large particles have to be comminuted to small particles before they can leave the rumen. However, quite high proportions of large particles have been found in the faeces (Bruining et al., 1998). This supports a more plausible hypothesis that large particles have a lower probability to escape from the rumen than small particles instead of no escape as proposed by Baldwin et al. (1987). Illius and Gordon (1991) and Sauvant et al. (1996) developed rumen intake models that consider the physical properties of the fibre fraction but for the other chemical fractions the description of the physical characteristics was poor or absent.

The objective of the present work has been to construct a simple rumen digestion model using both the physical and the chemical characteristics of the feed in order to predict rates of nutrient digestion and nutrient outflow as well as NDF pool sizes in the rumen of dairy cows at fixed rates of dry matter intake.

A further objective is to include this rumen model into a more general model of feed intake regulation. The purpose of this general model which will be described in a coming paper is to predict the voluntary feed intake of dairy cows fed different diets at different stages of lactation. The simulated rate of intake in this model will be regulated by physical as well as metabolic factors.

\section{METHODS}

\section{Model description}

The model is constructed as a dynamic, mechanistic and deterministic model according to the classification schemes given by France and Thornley (1984). The general structure of the model is shown in Figure 1. Nutrient pools (state variables) are depicted as boxes and flow rates (rate variables) are depicted as arrows. 
The model describes the rumen pools by means of differential equations with the general form:

$$
d \text { pool } / d t=\text { rates of inflow }- \text { rates of outflow. }
$$

With these equations, the rate of change in the mass of a given pool during a time interval $(d t)$ is equal to the sum of flow rates into the pool minus the sum of flow rates from the pool during this time interval. The current state, i.e. the mass of the pools, at a given time $(\mathrm{t})$ is calculated by numerical integration of the individual differential equations.

Hence, the model contains as many differential equations as there are pools. Most of How rates are described as first order mass action kinetics. This method has been adopted fully or partly in other rumen models (Mertens et al., 1979; Bywater, 1984; Baldwin et al., 1987; Danfar, 1990; Dijkstra et al., 1992, 1996b; Lescoat and Sauvant, 1995; Chilibroste et al., 1997).

No experiments were carried out during this work and therefore, parameter values are derived entirely from existing data, publisbed as well as unpublisbed. In the selection of data for model parameterisation and evaluation, experiments with dairy cows in the first or middle part of the lactation period have been preferred.

The state variables of the model are either carbon or nitrogen pools. Carbohydrates and lipids are represented as carbon (C) pools whereas protein and ammonium are represented as nitrogen $(\mathrm{N})$ pools. Units of mass used in the model are moles of carbon and moles of nitrogen for $\mathrm{C}$ and $\mathrm{N}$ pools, respectively. The contents of carbon and nitrogen in the dietary nutrients are taken as 37.037, 35.087 and 63.174 moles of $\mathrm{C}$ per $\mathrm{kg}$ polysaccharide, sugar and fat (tripalmitin), respectively and $11.423 \mathrm{mo-}$ les of $\mathrm{N}$ per $\mathrm{kg}$ crude protein. Units of flow are moles of $\mathrm{C}$ or $\mathrm{N}$ per hour.

The model is developed using the graphical modelling software Powersim ${ }^{2}$, version 2.5 (1996). Runge-Kutta 4th order integration method is used for the numerical solution of the differential equations with a time step of $0.05 \mathrm{~h}$. For model evaluation, the simulation time is $10 \mathrm{~d}$ in order to obtain steady states in the model. Then at the end of the simulation period, simulation results have been compared with corresponding experimental values.

\section{Model inputs}

To run the model, the following input parameters are required:

- Feed intake ( $\mathrm{kg} \mathrm{DM} \mathrm{d}$ ) and body weight (kg)

- Chemical composition of the diet (crude protein, sugar, starch, neutral detergent fibre (NDF), other carbohydrates, lipids, ash) ( $\left.\mathrm{g} \mathrm{kg}^{-1} \mathrm{DM}\right)$

- Physical characteristics of the diet (proportion of small particles, starch solubility, protein solubility) $(\%)$

- Potential rumen digestibility of crude protein and NDF (\%) and degradation rate constant of crude protein and NDF $\left(\mathrm{h}^{-1}\right)$. 


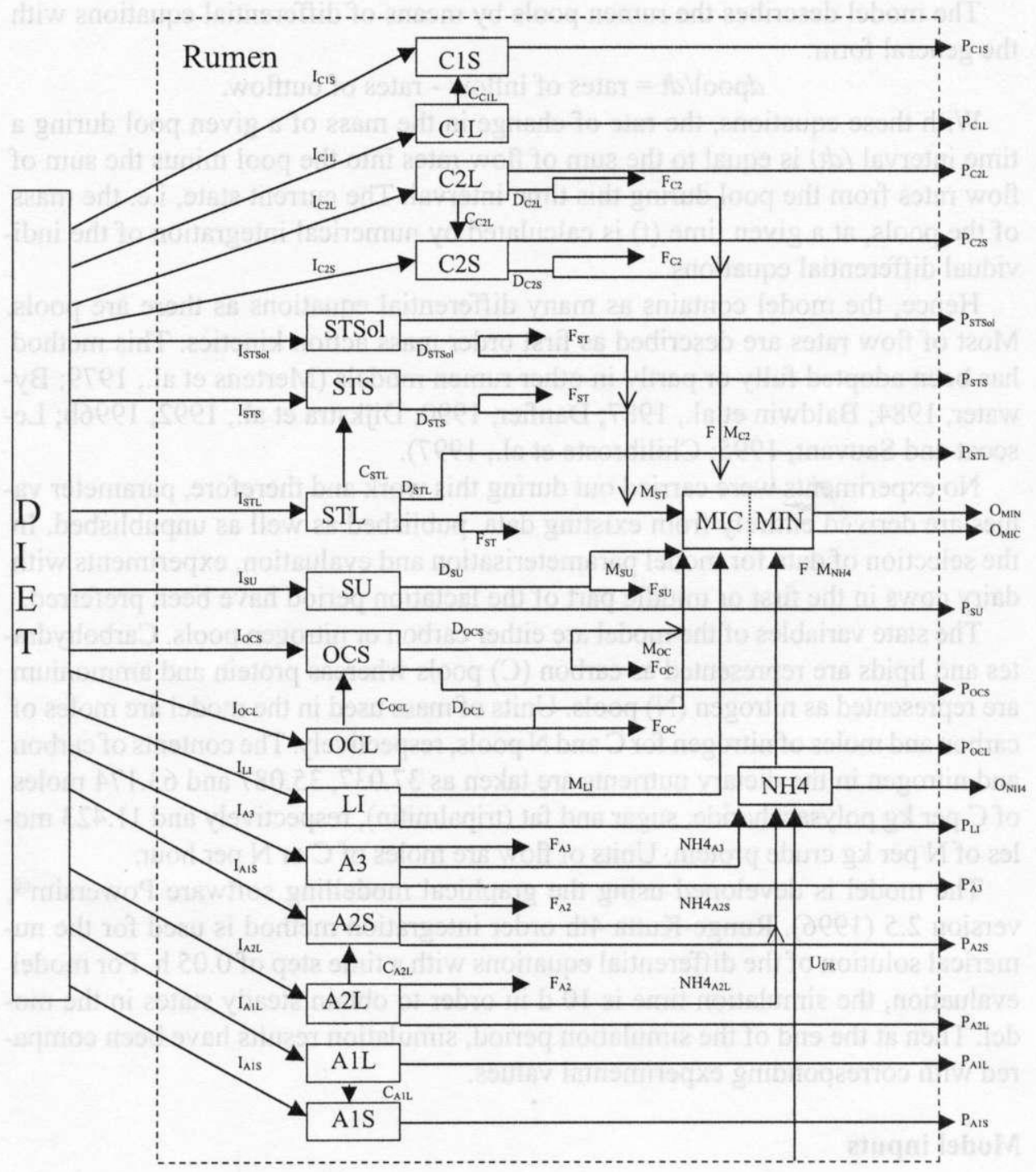

Figure 1. Flow diagram of the rumen model

The input parameters are transferred into the model from an Excel spreadsheet that contains a feed table from which specific diets to be evaluated by the model can be formulated. At the end of each simulation, some selected simulation results from the Powersim ${ }^{\circledR}$ model are transferred back to the spreadsheet for statistical analysis, presentation in a suitable form, etc. 


\section{Rumen pools}

\section{Carbohydrates}

Carbohydrates in the rumen model are divided into the following fractions: degradable and undegradable neutral detergent fibre, soluble and insoluble starch, sugars and other carbohydrates. This last fraction represents carbohydrates not included in other fractions, i.e. pectins, fructans and $\beta$-glucans.

In some rumen models (Forbes, 1980; Illius and Gordon, 1991), lag pools are included in order to describe time periods in which the process of digestion has not yet started or is very slow. The gradual transition from the lag phase to the digestion process is not well described in a model by a discontinuous process like a lag pool. On the other hand, it is also unrealistic to assume that the digestion starts immediately after feed particles have entered the rumen. However, the predictive ability of this and other rumen models has not been significantly improved by application of lag pools although it will have an impact on rumen pool sizes (Bannink et al., 1997). Digestion is described without a lag phase in the present version of the model.

The process of particie degradation is a continuous process in the rumen involving solubilisation, comminution and microbial digestion. The probability of particle escape from the rumen is inversely related to particle size (Poppi et al., 1981; Faichney et al., 1989; Ahvenjarvi et al., 2001). Although the passage of feed particles out of the rumen is a more or less continuous process, a threshold or critical particle size has been used for modelling purposes to delimit pools with different probabilities of ruminal escape (Ulyatt et al., 1986). This approach has been adopted in several rumen studies ranging in threshold values from I to $4 \mathrm{~mm}(1.1$ mm, Ahvenjarvi et al., 2001; 1.18 mm, Poppi et al., 1985; 1-2.5 mm, Bosch et al., 1995; $3.6 \mathrm{~mm}$, Shaver et al., 1988; 2-4 mm, Ulyatt et al., 1986). In all cases, the amount of particles greater than the critical size decreases and the amount of particles smaller than this increases with time after feeding. In the present model, the threshold particle size is defined as $1.18 \mathrm{~mm}$.

\section{$N D F$}

There are four NDF pools in the rumen defined according to degradability and particle size (Figure 1): undegradable large (C1L), undegradable small (C1S), potentially degradable large (C2L) and potentially degradable small (C2S) NDF particles. As mentioned above, large particles are defined as larger than $1.18 \mathrm{~mm}$ and small particles are those equal to or below this size.

The rate constant for passage of small NDF particles (CS) from the rumen is related to feed intake (DMI, $\mathrm{kg} \mathrm{h}^{-1}$ ) and is calculated in the model with the following equation: 


$$
\mathrm{Kp}_{\mathrm{sp}}=a+b \times\left(1-\exp \left(-c \times \mathrm{DMI}^{\star}\right)\right.
$$

were: $a, b, c$ and $d$ are parameters with values $0.01,0.052,1.85$ and 3.2 , respectively.

The large NDF particles (CL) are considered to have a much lower passage rate than the small particles and the passage rate constant of CL particles is taken in the model as $13 \%$ of that of CS particles $(\alpha=0.13)$. This value is derived as an average of values reported by Illius and Gordon (1991) and Bruining et al. (1998).

The rate constant of comminution from large to small particles $\left(\mathrm{K}_{\mathrm{en}}\right)$ is calculated according to the equation reported by Illius and Gordon (1991), that depends on the proportion of undegradable NDF in the diet and body weight.

The $\mathrm{C} 1 \mathrm{~L}$ pool has one inflow (dietary intake, $\mathrm{I}_{\mathrm{C} \text {. }}$ ) and two outflows (breakdown to small particles, $\mathrm{C}_{\mathrm{ClL}}$, and passage from the rumen, $\mathrm{P}_{\mathrm{CIL}}$ ). The $\mathrm{C} 1 \mathrm{~S}$ pool receives two inflows (dictary intake, $\mathrm{I}_{\mathrm{CIS}}$, and breakdown from large particles, $\mathrm{C}_{\mathrm{ClL}}$ ) and has one outflow (passage from the rumen, $\mathrm{P}_{\mathrm{CIS}}$ ).

The $\mathrm{C} 2 \mathrm{~L}$ and $\mathrm{C} 2 \mathrm{~S}$ pools have the same inputs and outputs as described for $\mathrm{C} 1 \mathrm{~L}$ and CIS, respectively and in addition to this one outflow from each pool representing digestion, $\left(D_{C_{22}}\right)$ and $\left(D_{C 2 S}\right)$. $D_{C 2}$ is the sum of these last two values. Part of this total digested NDF represents carbon taken up by microbes $\left(\mathrm{M}_{\mathrm{C} 2}\right)$ and the rest is the fraction that is available to be converted to VFA and fermentation gases $\left(\mathrm{F}_{\mathrm{C}_{2}}\right)$.

The rate of microbial uptake $\left(\mathrm{M}_{\mathrm{C} 2}\right)$ is calculated as the total carbohydrate $\mathrm{C}$ required by the microbes $\left(\mathrm{M}_{\mathrm{CHO}}\right)$ times the ratio of $\mathrm{D}_{\mathrm{C} 2}$ to the sum of all digested carbohydrate (NDF, sugar, starch and other carbohydrates). Fermented NDF $\left(\mathrm{F}_{\mathrm{C}_{2}}\right)$ is obtained by subtracting $M_{C 2}$ from the total digested NDF $\left(D_{C 2}\right)$. The microbial uptake and fermentation from the remaining digestible $\mathrm{CHO}$ pools are calculated according to the same principle.

Although some evidence suggests that particle size will affect the fractional rate of NDF digestion (Kd) at lcast for some forages (Robles et al., 1980), the results found in the literature are not consistent. Bruining et al. (1998) reported significant or no difference in the degradation rates of large and small rumen particles depending on the method used to determine the rates or the forage source considered. Oosting et al. (1994) found no significant differences in the Kd values of small or large particles of wheat-straw-based diets incubated in rumen. The same digestion rate constant is used here for both large and small particles. Illius and Gordon (1991) adopted the same principle in their digestion model. In the present model, this rate constant is given as an input from the experiment or calculated by the following equation:

$$
\mathrm{Kdg} \_\mathrm{C} 2=\mathrm{Kdm} \_\mathrm{NDF} \times(1-\exp (-\beta \times \text { Ratio })), h^{-1}
$$

where: $\mathrm{Kdm} \_$NDF is the maximum digestion rate constant of NDF; $\beta$ is a constant and Ratio is the ratio of digestible NDF to total digestible carbohydrates in the diet. 
This means that an increased proportion of easily digestible carbohydrates (primarily sugar and starch) in the diet decreases the digestion rate of NDF. The values for $\mathrm{Kdm}$ NDF and $\beta$, were estimated as $0.09 \mathrm{~h}^{-1}$ and 1.39 , respectively from a series of experiments in the Nordic countries.

\section{Starch}

Starch is a major source of energy in most diets fed to high producing dairy cows contributing with $20 \%$ or more of feed dry matter. An adequate description of the chemical and physical structure of starch entering the rumen is of great importance to obtain good predictions of starch digestion in the rumen. The undegraded proportion of starch is insignificant after $48 \mathrm{~h}$ of $i n$ situ incubation in the rumen (Mills et al., 1999) and the starch fraction is therefore assumed to be totally fermentable. Starch is represented in the model by three pools (Figure 1), i.e. soluble starch (STSol), insoluble large particle (STL) and insoluble small particle starch (STS).

There is one inflow to STSol (dietary intake, $\mathrm{I}_{\text {STSol }}$ ) and two outflows (passage, $\mathrm{P}_{\text {STSol }}$, and digestion, $\mathrm{D}_{\mathrm{STSO} \text {. }}$. The soluble starch is assumed to leave the rumen with the same rate constant as the liquid phase The rate constant for the liquid phase is calculated in the model with the following equation:

$$
\mathrm{Kp}_{\mathrm{LIQ}}=\gamma \times\left(1-\exp \left(-\delta \times\left(1000 \times \mathrm{I}_{-} \mathrm{NDF} / \mathrm{BW}\right)^{\theta}\right), \mathrm{h}^{-1}\right.
$$

were: I_NDF is intake of NDF ( $\left.\mathrm{kg} \mathrm{day}^{-1}\right), \mathrm{BW}$ is body weight $(\mathrm{kg})$ and $\gamma, \delta$ and $\theta$ are parameters with values $0.18,0.03$ and 1.45 , respectively derived from a database of Nordic experiments.

The STL pool has one inflow $\left(\mathrm{I}_{\mathrm{STL}}\right)$ and three outflows, i.e. passage $\left(\mathrm{P}_{\mathrm{STL}}\right)$, digestion $\left(\mathrm{D}_{\mathrm{STL}}\right)$ and breakdown to small particles $\left(\mathrm{C}_{\mathrm{STL}}\right)$. The rate constant of comminution from large to small starch particles is the same as that used for NDF. The passage rate constants for the insoluble starch fractions (large and small particles) are calculated as those for NDF large and small particles.

The inflows to STS are dietary intake $\left(\mathrm{I}_{\mathrm{STS}}\right)$ and breakdown from large particles $\left(\mathrm{C}_{\mathrm{STL}}\right)$. The two outflows are passage and digestion, i.e. $\mathrm{P}_{\mathrm{STL}}$ and $\mathrm{D}_{\mathrm{STL}}$, respectively. The digestion rate constants for soluble and insoluble starch are given as inputs to the model. When sensitivity analyses are performed, these values are $1.5 \mathrm{~h}^{-1}$ and $0.35 \mathrm{~h}^{-1}$, respectively (Volden, personal communication). Galyean et al. (1981) and Mills et al. (1999) have shown that reduction of the particle size in grains by grinding can affect the degradation rate of starch, but due to lack of reliable quantitative data the same fermentation rate constant is used in the model for both large and small starch particles. 
Sugars

Dietary sugars (SU) are assumed to be totally soluble and fermentable in the rumen and no distinction due to particle size is done for this fraction. The rate of intake is $\mathrm{I}_{\mathrm{su}}$ and the rates of outflow are $\mathrm{P}_{\mathrm{Su}}$ (passage) and $\mathrm{D}_{\mathrm{su}}$ (digestion). The passage rate constant is that of the liquid phase and the digestion rate constant is the same as for soluble starch, i.e. $1.5 \mathrm{~h}^{-1}$ (Volden, personal communication).

\section{Other carbohydrates}

This fraction is divided in two pools according to the particle size OCL and OCS, other carbohydrates large and small pool, respectively. Each of these pools has a dietary input $\left(\mathrm{I}_{O C L}\right.$ or $\left.\mathrm{I}_{O C S}\right)$ and two outputs, passage $\left(\mathrm{P}_{O C L}\right.$ or $\left.\mathrm{P}_{O C S}\right)$, and digestion $\left(\mathrm{D}_{\mathrm{OCL}}\right.$ or $\mathrm{D}_{\mathrm{OCS}}$ ). There is also a flow from OCL to OCS representing breakdown from large to small particles $\left(\mathrm{C}_{\mathrm{OCl}}\right)$ at the same rate constant as for NDF or starch fractions. $I_{O C}$ is calculated as one minus the sum of the proportions of the remaining chemical fractions (NDF, starch, sugars, ash, lipids and protein). The passage rate constants for the outflow from the OCL or OCS pools are the same as those for NDF large and small particles The digestion rate constant is equal to that of insoluble starch.

\section{Protein}

There are five protein pools in the model defined according to solubility, degradability and particle size. Two insoluble undegradable crude protein pools (AlL and AIS), two insoluble potentially degradable crude protein pools (A2L, A2S) and one soluble crude protein pool (A3). The flows to and from the AIL and A1S pools are the same as those described for the undegradable NDF fractions. A2L has one inflow $\left(\mathrm{I}_{\mathrm{A} 2 \mathrm{~L}}\right.$ ) and three outflows, $\mathrm{P}_{\mathrm{A} 2 \mathrm{~L}}, \mathrm{C}_{\mathrm{A} 2 \mathrm{~L}}$ and $\mathrm{NH}_{\mathrm{A} 2 \mathrm{~L}}$ representing passage to duodenum, comminution and degradation, respectively. The $\mathrm{I}_{\mathrm{A} 2 \mathrm{~S}}$ and $\mathrm{C}_{\mathrm{A} 2 \mathrm{~L}}$. represent the two inputs from diet and comminution from large particles, respectively, to the A2S pool and the outflows from this pool are passage to duodenum $\left(\mathrm{P}_{\mathrm{AS}}\right)$ and degradation $\left(\mathrm{NH}_{\mathrm{A} 2 \mathrm{~S}}\right)$. The passage rate constant for the large or small crude protein fractions are the same as those used for the respective NDF fractions. $I_{A 3}$ represents the dictary input to the soluble crude protein pool and $P_{A 3}$ and $\mathrm{NH} 4_{A 3}$, passage and digestion, the two outflows from the $\mathrm{A} 3$ pool. Soluble protein flows from the rumen with the same rate constant as the liquid phase. The degradation rate constants for soluble or insoluble crude protein fractions are given as inputs to the model. All carbon from the fermentation of protein is to be converted to VFA and fermentation gases $\left(\mathrm{F}_{\mathrm{A}}\right)$. The molar ratio of $\mathrm{C}$ to $\mathrm{N}$ in proteins $(\mathrm{KCN})$ is taken as 3.8 (Reichl et al., 1975; Danfær, 1990). 


\section{Lipids}

The rumen lipids are represented as a zero pool (LI) in the model as it is assumed that a constant fraction of the dietary input $\left(I_{L .1}\right)$ passes through the rumen $\left(\mathrm{P}_{t . .}\right)$ and the remaining fraction is taken up by the microbes $\left(\mathrm{M}_{\mathrm{L} . \mathrm{l}}\right)$. The ratio of passage to microbial uptake is $9: 1$.

\section{Microbes}

The rumen microbes are represented by two pools in the model (Figure 1), microbial N (MIN) and microbial C (MIC). The chemical composition of the microbial population is assumed to be constant at (\% of DM): crude protein 51.0 , cell wall carbohydrates 9.5 , starch 13.7 , lipids 10.8 and ash 15.0. These values are derived from experimental results on microbial chemical composition at different feed intake levels and different diet compositions (Storm and Ørskov, 1983; Hvelplund, 1986; Dijkstra et al., 1992, 1996b; Volden and Harstad, 1998). With this chemical composition, the ratio of total $\mathrm{C}$ to total $\mathrm{N}$ in the rnicrobes can be calculated as 6.45 on a molar basis.

The inflow to MIN is uptake of ammonium for protein synthesis. The rate of this process $\left(\mathrm{M}_{\mathrm{NH} 4}\right)$ is related to feed intake and to fermentation of carbohydrates in the following way:

$$
\begin{aligned}
& \mathrm{M}_{\mathrm{NB} 4}=\mathrm{NH} 4 \times \mathrm{Kup} \_\mathrm{NH} 4 \times \mathrm{e} \times \mathrm{F} \_\mathrm{CHO}, \mathrm{mol} \mathrm{N} \mathrm{h}{ }^{-1} \\
& \text { Kup_NH4 }=\bar{f} \times\left(1-\exp \left(-g \times \mathrm{DMI}^{h}\right)\right), \mathrm{h}^{-1}
\end{aligned}
$$

where: F_CHO is the total fermentation rate of carbohydrates; $e, f, g$ and $h$ are constants with values $0.265,1.5782,1.85$ and 1.19 , respectively derived from data reported by Volden (1999) for diets HL.

The MIC pool has five inflows: $M_{C 2}, M_{S \Gamma}, M_{S U}, M_{O C}$ and $M_{1.1}$ representing uptake of NDF, starch, sugar, other carbohydrates and lipid, respectively. Total $\mathrm{C}$ required by microbes is calculated as $\mathrm{M}_{\mathrm{NH} 4}$ times the ratio of total $\mathrm{C}$ to total $\mathrm{N}$ in the microbes. If from this total $\mathrm{C}$ is subtracted the $\mathrm{C}$ provided by lipids $\left(\mathrm{M}_{\mathrm{LI}}\right)$, the rest fraction is the $\mathrm{C}$ that should be supplied by carbohydrates $\left(\mathrm{M}_{\mathrm{CHO}}\right)$. Passage out of the rumen $\left(\mathrm{O}_{\text {MIN }}\right.$ and $\left.\mathrm{O}_{\text {MIC }}\right)$ are the only outflows from MIN and MIC, respectively.

Given that rumen microbes are distributed both in the liquid and the solid phase, the microbial outflow rate constant should be estimated from the rate constants of these phases in proportion to the microbial distribution between them. However, the proportion of microbes attached to the particulate fraction varies according to different authors (Illius and Gordon, 1991; Dijkstra et al., 1996b; Lykos et al., 1997) and there is not yet any precise and reproducible method to distingu- 
ish between free and particie attached microbes in duodenal samples (Volden and Harstad, 1998). In the model the passage rate constant for microbes $\left(\mathrm{Kfl}_{\mathrm{MI}}\right)$ is calculated as:

$$
\mathrm{Kff}_{\mathrm{MI}}=0.66 \times \mathrm{Kp}_{\mathrm{NDF}}+0.34 \times \mathrm{Kp}_{\mathrm{LIQ}}, \mathrm{h}^{-1}
$$

where $K_{p} N D F$ is a weighted average of the passage rate constant for small and large NDF particles from the rumen, and $\mathrm{Kp}_{\mathrm{LIV}}$ the passage rate constant of liquid as defined earlier. The proportion of microbes attached to solid or liquid phase was taken from Volden (1999).

\section{Ammonium}

The ammonium pool $\left(\mathrm{NH}_{4}\right)$ has inputs from urea uptake $\left(\mathrm{U}_{\mathrm{UR}}\right)$ and from protein degradation ( $\mathrm{NH}_{4}$ ). $\mathrm{U}_{\mathrm{UR}}$ is $0.184 \mathrm{~mol} \mathrm{~N} \mathrm{~h}^{-1}$, a value taken from Hvelplund (1983). Outflows from $\mathrm{NH}_{4}$ are uptake by microbes $\left(\mathrm{M}_{\mathrm{iH4}}\right)$, passage from the rumen with the liquid phase $\left(\mathrm{O}_{\mathrm{NH} 4}\right)$ and absorption through the rumen wall $\left(\mathrm{Ab}_{\mathrm{NH} 44}\right)$ The rate constant for absorption is $0.45 \mathrm{~h}^{-1}$.

Outflow of ammonium from the rumen follows the liquid fractional passage rate. The rate constant of uptake of ammonium by microbes was calculated from data presented by Volden (1999) and is affected by the level of feed intake and by the total amount of fermented carbohydrates in the rumen as explained above.

\section{Model evaluation}

In order to test the internal and external validity of the model performance, two types of evaluations were made: a sensitivity analysis and a comparative analysis.

The sensitivity test examined the effects of systematic changes in some parameter values on selected output variables.

The parameters chosen to be changed (with the abbreviation and original value in brackets) were: parameters $a(0.01), b(0.052), c(1.85)$, and $d(3.2)$, defining the passage rate constant of small particles; correction factor for passage of large particles out of rumen $(\alpha=0.13)$; digestion rate constant of sugars $(\mathrm{Kd}$ _SU $=1.5$ $\mathrm{h}^{-1}$ ); digestion rate constant of soluble starch $\left(\mathrm{Kd}_{-} \mathrm{STSOl}=1.5 \mathrm{~h}^{-1}\right)$; absorption rate constant of ammonium ( KabNH4 $=0.45 \mathrm{~h}^{-1}$ ); maximum digestion rate constant of NDF (Kdm_NDF $=0.09 \mathrm{~h}^{-1}, \beta(1.39)$, lipid fraction taken up by microbes (Kd_LI $=0.1$ ) and parameters $f(1.5782), g(1.85)$ and $h(1.19)$ in the equation defining microbial uptake of ammonium. The original values of these parameters were modified by $\pm 5, \pm 25$ or $\pm 50 \%$.

The outputs selected to evaluate the changes were: neutral detergent fibre degradability; total organic matter outflow; total, dietary and microbial nitrogen outflow, 
starch digestibility and NDF pools grouped as: total NDF pool (T_NDF $=$ ClL + $\mathrm{C} 1 \mathrm{~S}+\mathrm{C} 2 \mathrm{~L}+\mathrm{C} 2 \mathrm{~S})$; undegradable NDF pool $(\mathrm{INDF}=\mathrm{C} 1 \mathrm{~L}+\mathrm{C} 1 \mathrm{~L})$; potentially degradable NDF pool (DNDF $=\mathrm{C} 2 \mathrm{~L}+\mathrm{C} 2 \mathrm{~S}$ ); large NDF particles pool ( L-NDFp $=\mathrm{C} 1 \mathrm{~L}+\mathrm{C} 2 \mathrm{~L})$ and small NDF particles pool in rumen $\left(\mathrm{S}_{-} \mathrm{NDF}_{\mathrm{p}}=\mathrm{C} 1 \mathrm{~S}+\mathrm{C} 2 \mathrm{~S}\right)$.

TABLE

Ingredients, composition and intake of diets used for sensitivity analysis

\begin{tabular}{lcc}
\hline Ingredients, \% of DM & $\mathrm{HH}-\mathrm{H}$ & $\mathrm{LL}-\mathrm{L}$ \\
\hline Grass silage & 40.0 & 40.0 \\
Barley & 22.6 & 26.1 \\
Oats & 22.8 & 25.1 \\
Fish meal $^{\mathrm{s}}$ & 4.8 & 0 \\
Fish meal $^{\mathrm{b}}$ & 0 & 2.1 \\
Soyabean meal $_{\text {Rape seed }}$ & 0 & 3.6 \\
Rapeseed meal & 0.6 & 0.6 \\
Molasses & 0.6 & 0.6 \\
Mincrals and vitamins & 3.6 & 3.6 \\
& 1.9 & 1.9 \\
Chemical composition, $\mathrm{g} \mathrm{kg}{ }^{-1}$ of DM & & \\
NDF & 365 & 383 \\
crude protein & 174 & 148 \\
starch & 249 & 274 \\
lipids & 41 & 39 \\
ruminally undegraded protein & 53 & 48 \\
Intake, kg DM d & & \\
\hline
\end{tabular}

$\mathrm{a}$ and $\mathrm{b}$ : effective protein degradability of 24 and $65 \%$, respectively, calculated at a ruminal outflow rate of $8 \% \mathrm{~h}^{-1}$

The diets used in the sensitivity analysis were two of the diets ( $\mathrm{HH}-\mathrm{H}$ and LLL) used by Volden (1999). Ingredients, chemical composition and daily intake of these diets are presented in Table 1. The diets differ in crude protein content and degradability as well as level of feed intake. Ingredients and composition of the individual components of the diets were obtained from information given in the published study, by personal communication with the author and from the Danish Feed Table (Møller et al., 2000).

The HH-H diet had a high protein content, high protein degradability and was fed at a high level of intake ( $19 \mathrm{~kg} \mathrm{DM} \mathrm{d}^{-1}$ ), whereas the LL-L diet had a low protein content of low degradability and was fed at a low level of feed intake $(10 \mathrm{~kg}$ $\left.\mathrm{DM} \mathrm{d}^{-1}\right)$. 
The second test, behavioural or comparative analysis, was used to examine if for a range of different inputs the model yields a set of outputs in agreement with experimental observations. For this purpose 25 experimental diets from five different experiments differing widely in intake level and diet composition, were selected. A detailed description of the diets used to validate the model is presented in Tables 2 and 3.

TABLE 2

Description of the diets used for external validation of the rumen model

\begin{tabular}{|c|c|c|c|c|c|}
\hline Author & Treatments & Type of forage & $\begin{array}{l}\text { Grain type and } \\
\text { processing }\end{array}$ & $\begin{array}{l}\mathrm{DMI}^{*} \\
\mathrm{~kg} \mathrm{day}^{-1}\end{array}$ & $\begin{array}{l}\text { Diet } \\
\text { number }\end{array}$ \\
\hline \multirow[t]{4}{*}{ Yang et al., 2000} & Coarse $^{a}$ & $\begin{array}{l}\text { Barley silage } \\
\text { Lucerne silage } \\
\text { Lucerne hay }\end{array}$ & Barley & 18.7 & I \\
\hline & Mediuma & $\begin{array}{l}\text { Barley silage } \\
\text { Lucerne silage } \\
\text { Luceme hay }\end{array}$ & Barley & 21.4 & 2 \\
\hline & $\begin{array}{l}\text { Medium } \\
\text { Flat }^{\mathrm{a}}\end{array}$ & $\begin{array}{l}\text { Barley silage } \\
\text { Lucerne silage } \\
\text { Lucerne hay }\end{array}$ & Barley & 21.7 & 3 \\
\hline & Flat $^{a}$ & $\begin{array}{l}\text { Barley silage } \\
\text { Lucerne silage } \\
\text { Lucerne hay }\end{array}$ & Barley & 20.1 & 4 \\
\hline \multirow[t]{4}{*}{ Crocker et al., 1998} & DR $100^{\mathrm{h}}$ & Lucerne hay & Dry rolled corn & 17.7 & 5 \\
\hline & DR $67^{\circ}$ & Lucerne hay & $\begin{array}{l}\text { Dry rolled ma- } \\
\text { ize - Steam- fla- } \\
\text { ked coin }\end{array}$ & 19.1 & 6 \\
\hline & $\mathrm{DR} 33^{\mathrm{b}}$ & Lucenc bay & $\begin{array}{l}\text { Dry rolled ma- } \\
\text { ize - Steam- fla- } \\
\text { ked corn }\end{array}$ & 18.9 & 7 \\
\hline & DR $\quad 0^{\mathrm{h}}$ & Lucerne hay & $\begin{array}{l}\text { Steain-flaked } \\
\text { maize }\end{array}$ & 18.1 & 8 \\
\hline \multirow[t]{5}{*}{ Overton et al., 1995} & $100: 0^{\circ}$ & $\begin{array}{l}\text { Lucerne silage } \\
\text { Maize silage }\end{array}$ & $\begin{array}{l}\text { Ground shelled } \\
\text { maize }\end{array}$ & 22.8 & 9 \\
\hline & $75: 25^{c}$ & $\begin{array}{l}\text { Lucerne silage } \\
\text { Maize silage }\end{array}$ & $\begin{array}{l}\text { Ground shelled } \\
\text { maize - Stcam- } \\
\text { rolled bariey }\end{array}$ & 22.1 & 10 \\
\hline & $50: 50^{\circ}$ & $\begin{array}{l}\text { Lucerne silage } \\
\text { Maize silage }\end{array}$ & $\begin{array}{l}\text { Ground shelled } \\
\text { maize - Steam- } \\
\text { rolled barley }\end{array}$ & 21.3 & 11 \\
\hline & $25: 75^{\mathrm{c}}$ & $\begin{array}{l}\text { Lucerne silage } \\
\text { Maize silage }\end{array}$ & $\begin{array}{l}\text { Ground shelled } \\
\text { maize - Steam- } \\
\text { rolled barley }\end{array}$ & 19.5 & 12 \\
\hline & $0: 100^{\mathrm{c}}$ & $\begin{array}{l}\text { Lucerne silage } \\
\text { Maize silage }\end{array}$ & $\begin{array}{l}\text { Steam- rolled } \\
\text { barley }\end{array}$ & 19.6 & 13 \\
\hline
\end{tabular}


TABLE 2 continued

Description of the diets used for external validation of the rumen model

\begin{tabular}{|c|c|c|c|c|c|}
\hline Author & Treatments & Type of forage & $\begin{array}{l}\text { Grain type and } \\
\text { processing }\end{array}$ & $\begin{array}{l}\mathrm{DMI}^{*} \\
\mathrm{~kg} \mathrm{day}^{-1}\end{array}$ & $\begin{array}{l}\text { Dict } \\
\text { number }\end{array}$ \\
\hline \multirow[t]{4}{*}{ Volden, 1999} & $\mathrm{BO}$ & Grass silage & Barley and oats & 17.5 & 14 \\
\hline & $\mathrm{BOU}$ & Grass silage & Barley and oats & 17.7 & 15 \\
\hline & SB & Grass silage & Barley and oats & 18.2 & 16 \\
\hline & SBU & Grass silage & Barley and oats & 17.5 & 17 \\
\hline \multirow[t]{8}{*}{ Lund, 2002} & GH & Grass liay & No supplement & 8.35 & 18 \\
\hline & EGS & $\begin{array}{l}\text { Early cut grass } \\
\text { silage }\end{array}$ & No supplement & 10.5 & 19 \\
\hline & LGS & $\begin{array}{l}\text { Late cut grass } \\
\text { silage }\end{array}$ & No supplement & 8.18 & 20 \\
\hline & WCBS & $\begin{array}{l}\text { Whole crop } \\
\text { barley silage }\end{array}$ & $\begin{array}{l}\text { No } \\
\text { supplenented }\end{array}$ & 12.7 & 21 \\
\hline & $\mathrm{GH}$ & Grass hay & $\begin{array}{l}\text { Wheat meal } \\
\text { - soyabean incal }\end{array}$ & 13.7 & 22 \\
\hline & EGS & $\begin{array}{l}\text { Early grass } \\
\text { silage }\end{array}$ & $\begin{array}{l}\text { Wheat meal } \\
\text { - soyabean meal }\end{array}$ & 15.3 & 23 \\
\hline & LGS & $\begin{array}{l}\text { Late grass } \\
\text { silage }\end{array}$ & $\begin{array}{l}\text { Wheat meal } \\
\text { - soyabean meal }\end{array}$ & 15.5 & 24 \\
\hline & WCBS & $\begin{array}{l}\text { Whole crop } \\
\text { barley silage }\end{array}$ & $\begin{array}{l}\text { Wheat meal } \\
\text { - soyabean meal }\end{array}$ & 15.5 & 25 \\
\hline
\end{tabular}

$\because$ dry matter intake

": degree of barley grain processing

b: ratio of dry-rolled to steam-flaked maize in diets

$\because$ ratio of maize starch to barley starch in diets

d: HH or LL represent diets with high protein content with high ruminal degradability or low protein content with low ruminal degradability, respectively

The information about chemical composition and physical characteristics of the diets used for validation corresponds to the information given by the authors. If some information was missing, different sources were used to estimate the input values.

Neutral detergent fibre digestion parameters for the diets 5 to 13 used for external validation were estimated from Haddad and Grant (2000) with the following values: Kdm_NDF (0.06408); $\beta$ (3.3775) and Ratio is the ratio of potentially digestible NDF to total potentially digestible carbohydrates in the diet, but excluding starch from maize grain.

Experiments 1 to 4 correspond to the study of Yang et al. (2000). Values of chemical composition not reported by the authors were taken from the Danish Feedstuff Table, and starch degradation parameters from Tamminga et al. (1990). Information about particle size was taken from the paper itself and from Mertens (1997). In this experiment barley grain with different degree of processing was used as a supplement. 
TABLE 3

Chemical and physical description, on a DM basis, of diets used during external validation

\begin{tabular}{|c|c|c|c|c|c|c|c|c|}
\hline $\begin{array}{c}\text { Diet } \\
\text { number }\end{array}$ & $\begin{array}{c}\text { Organic } \\
\text { mater } \\
\%\end{array}$ & $\begin{array}{c}\text { Crude } \\
\text { protein } \\
\%\end{array}$ & $\begin{array}{c}\mathrm{NDF} \\
\%\end{array}$ & $\begin{array}{c}\text { DNDF* } \\
\%\end{array}$ & $\begin{array}{c}\text { Smal! } \\
\text { NDF } \\
\text { partic- } \\
\text { les } \\
\%\end{array}$ & $\begin{array}{c}\text { Starch } \\
\%\end{array}$ & $\begin{array}{c}\text { Soluble } \\
\text { starch } \\
\%\end{array}$ & $\begin{array}{l}\text { Sinall } \\
\text { starch } \\
\text { partic- } \\
\text { les } \\
\%\end{array}$ \\
\hline 1 to 4 & 91.5 & 16.7 & 35.6 & 69.5 & 9.1 & 31.7 & 69.8 & $28 .-4.7$ \\
\hline 5 & 91.9 & 18.0 & 32.4 & 61.0 & 27.2 & 19.3 & 18.5 & 14.8 \\
\hline 6 & 92.1 & 17.4 & 32.5 & 60.9 & 26.8 & 21.0 & 24.6 & 11.9 \\
\hline 7 & 91.9 & 17.2 & 32.0 & 60.9 & 26.7 & 20.1 & 33.5 & 9.0 \\
\hline 8 & 91.8 & 17.6 & 32.3 & 60.8 & 26.1 & 19.4 & 42.8 & 5.1 \\
\hline 9 & 91.9 & 16.3 & 33.8 & 51.4 & 18.9 & 33.0 & 36.5 & 37.9 \\
\hline 10 & 92.1 & 16.0 & 33.7 & 51.2 & 19.0 & 33.0 & 43.6 & 36.6 \\
\hline 11 & 92.2 & 16.2 & 33.9 & $5 ! .2$ & 19.0 & 32.6 & 51.2 & 35.4 \\
\hline 12 & 92.3 & 16.2 & 35.0 & 50.8 & 18.5 & 32.8 & 58.0 & 33.0 \\
\hline 13 & 92.9 & 16.1 & 36.5 & 50.7 & 17.8 & 33.1 & 64.6 & 29.5 \\
\hline 14 & 92.9 & 11.1 & 23.1 & 75.2 & 15.5 & 25.4 & 44.5 & 46.6 \\
\hline 15 & 13.8 & & 22.0 & 75.9 & 14.2 & 25.0 & 44.5 & 46.6 \\
\hline 16 & 92.9 & 16.3 & 21.8 & 76.3 & 14.7 & 22.1 & 44.7 & 49.0 \\
\hline 17 & 92.9 & 18.0 & 23.6 & 77.0 & 16.2 & 23.1 & 44.6 & 49.1 \\
\hline 18 & 94.6 & 11.4 & 62.2 & 78.4 & 1.7 & 2.7 & 50.0 & 1.7 \\
\hline 19 & 89.5 & 17.5 & 47.0 & 89.9 & 1.7 & 0 & 0 & 0 \\
\hline 20 & 91.7 & 11.1 & 62.1 & 78.7 & 1.7 & 0 & 0 & 0 \\
\hline 21 & 93.7 & 13.6 & 43.8 & 71.2 & 5.0 & 24.2 & 64.5 & 5.0 \\
\hline 22 & 95.6 & 14.0 & 39.1 & 80.6 & 6.2 & 27.5 & 86.0 & 82.7 \\
\hline 23 & 92.2 & 17.8 & 30.0 & 87.6 & 6.9 & 23.8 & 86.9 & 90.6 \\
\hline 24 & 93.5 & 14.6 & 38.8 & 77.6 & 5.6 & 24.1 & 86.9 & 90.6 \\
\hline 25 & 94.8 & 15.5 & 29.8 & 73.4 & 9.8 & 36.5 & 79.1 & 39.8 \\
\hline
\end{tabular}

* potentially digestible NDF

Dry-rolled or steam-flaked maize in different proportions was used as a source of starch in experiments 5 to 8 (Crocker et al., 1998). The chemical composition of the different feedstuffs and the values of starch degradation were taken from the study itself and from the Danish Feedstuff Table. Particle size values were taken from the values presented by Mertens (1997) and Yu et al. (1998).

For the diets 9 to 13 (Overton et al., 1995), the starch degradation parameters were estimated and taken from Batajoo and Shaver (1998). The values of the particle size of the different feed ingredients were estimated from the values reported by 
Beauchemin et al. (1994), Mertens (1997) and Woodford and Murphy (1988). Different proportions of barley and maize grain were used in the different treatments.

For the diets 14 to 17 the chemical composition was obtained from Volden et al. (1999) and by information given by the authors. Information about particle size was taken from Beauchemin et al. (1994) and from Mertens (1997). Barley and oats were used as concentrate supplements in these diets.

The last 8 diets (Table 2) correspond to the experiments carried out by Lund (2002) with four different forages with or without supplementation. Information about chemical composition and particle size was taken from the paper itself and by personal communication with the author. Wheat meal and soyabean meal were used as supplement for the last four diets.

\section{Statistics}

To estimate the ability of the model to predict values regression analysis between observed and predicted values was used. Error of prediction was estimated according to Theil (1966) and defined as the root square of the ratio between mean square of the prediction error (MSPE) and the observed mean.

The MSPE was calculated as:

$$
\operatorname{MSPE}=\Sigma\left(\mathrm{O}_{i}-\mathrm{P}_{i}\right)^{2} / \mathrm{n}
$$

where $i=1.2 \ldots \mathrm{n} ; \mathrm{n}$ is the number of experimental observations; $\mathrm{O}_{\mathrm{i}}$ and $\mathrm{P}_{\mathrm{i}}$ are the observed and predicted values, respectively.

The MSPE was decomposed as defined by Bibby and Toutenberg (1977) into error in central tendency (ECT), error due to regression (ER) and crror due to disturbance (ED). Error in central tendency indicates how the average of predicted values deviates from the average of observed values. ER measures the deviation of the least squares regression coefficient from unity, the value it would have been if the predictions were completely accurate. ED is the unexplained variance and represents the portion of MSPE that cannot be eliminated by linear corrections of the predictions. When expressed in percentage of MSPE, ECT, ER and ED are called bias proportion, regression proportion and disturbance proportions, respectively, and are calculated as:

$$
\begin{aligned}
& \mathrm{ECT}=(\mathrm{P}-\mathrm{O})^{2} \\
& \mathrm{ER}=\left(\mathrm{S}_{\mathrm{p}}-\mathrm{rxS}_{\mathrm{O}}\right)^{2} \\
& \mathrm{ED}=\left(1-\mathrm{r}^{2} \times \mathrm{S}_{0}\right)^{2}
\end{aligned}
$$

where $P$ and $A$ are the averaged predicted and observed values, respectively; $S_{p}$ and $S_{0}$ are the standard deviations of the predicted and observed values, respectively; and $r$ is the coefficient of correlation between predicted and observed values. 


\section{RESULTS AND DISCUSSION}

\section{From the sensitivity analysis}

Tables 4 and 5 show the changes in the selected variables (in \%) when the parameter heading the row was increased or reduced by $50 \%$ from the original value for the LL-L diet (Volden, 1999).

The importance of rate of escape from the rumen of small particles and rate of particle size reduction has been recognised in experimental work as well as in modelling ruminal fibre digestion (Tamminga et al., 1989; Illius and Gordon, 1991; Mertens, 1993).

NDF degradability in the model is affected by the value of the parameters $a$, $b, \mathrm{c}$ and $d$ defining passage rate constant of small particles (Ksp) and to a lesser extent by the $\alpha$ factor. Considering both types of diets, the influence of the parameters in the equation defining Ksp_NDF on NDF digestibility is highest with the $\mathrm{HH}-\mathrm{H}$ diet (values not shown).

Total OM outflow is also influenced by the same parameters as NDF digestibility but to a lesser extent and the effect is more important with a reduction than with the increment of the original values. Parameters $f, g$, and $h$ also influence OM outflow, especially in the LL - L diet.

Total $\mathrm{N}$ outflow is affected by a large change in the original value of the rate constant of ammonium absorption (Kab_NH4) and the parameters $f$ and $g$. Microbial $\mathrm{N}$ outflow is highly sensitive to the same parameters affecting total $\mathrm{N}$ outflow and the effect is more significant with a reduction in the original value. Dietary $\mathrm{N}$ outflow is sensitive to the parameters $a, b, \mathrm{c}$ and $d$ as well as to the $\alpha$ parameter. All $\mathrm{N}$ outputs are more affected by the mentioned parameters when the LL-L diet is analysed.

Changes in the rate constant of sugar fermentation have only a small impact on the output variables selected and were in line with literature data (Weisbjerg et al., 1998). The minor changes predicted are possibly due to the low sugar content of the diets used and also to the high initial value of this parameter although a much higher value than that used in the present model has been reported by Weisbjerg et al. (1998). Even a decrease of 50\% from the initial value only allows a very small amount of sugars to escape from the rumen.

Apparent ruminal starch digestion is sensitive only to large changes in the $\mathrm{Kd}$ STSol constant mainly for the $\mathrm{HH}-\mathrm{H}$ diet. Extreme changes in the constant rate of lipid uptake by microbes $\left(\mathrm{Kd}_{-} \mathrm{LI}\right)$ only produce small variations in the $\mathrm{OM}$, total or microbial $\mathrm{N}$ outflow.

In general, NDF pools ( $\mathrm{T}_{-} \mathrm{NDF}_{\mathrm{p}}, \mathrm{INDF}_{\mathrm{p}}, \mathrm{DNDF}_{\mathrm{p}}, \mathrm{L}_{-} \mathrm{NDF}_{\mathrm{p}}$ and $\mathrm{S}_{-} \mathrm{NDF}_{\mathrm{p}}$ ) are strongly affected by the parameters in the equation of $\operatorname{Ksp}_{-} \mathrm{NDF}(a, b, c, d)$, by $\beta$ and by Kdm_NDF. Changes in $\alpha$ result in lower changes of the rumen NDF 


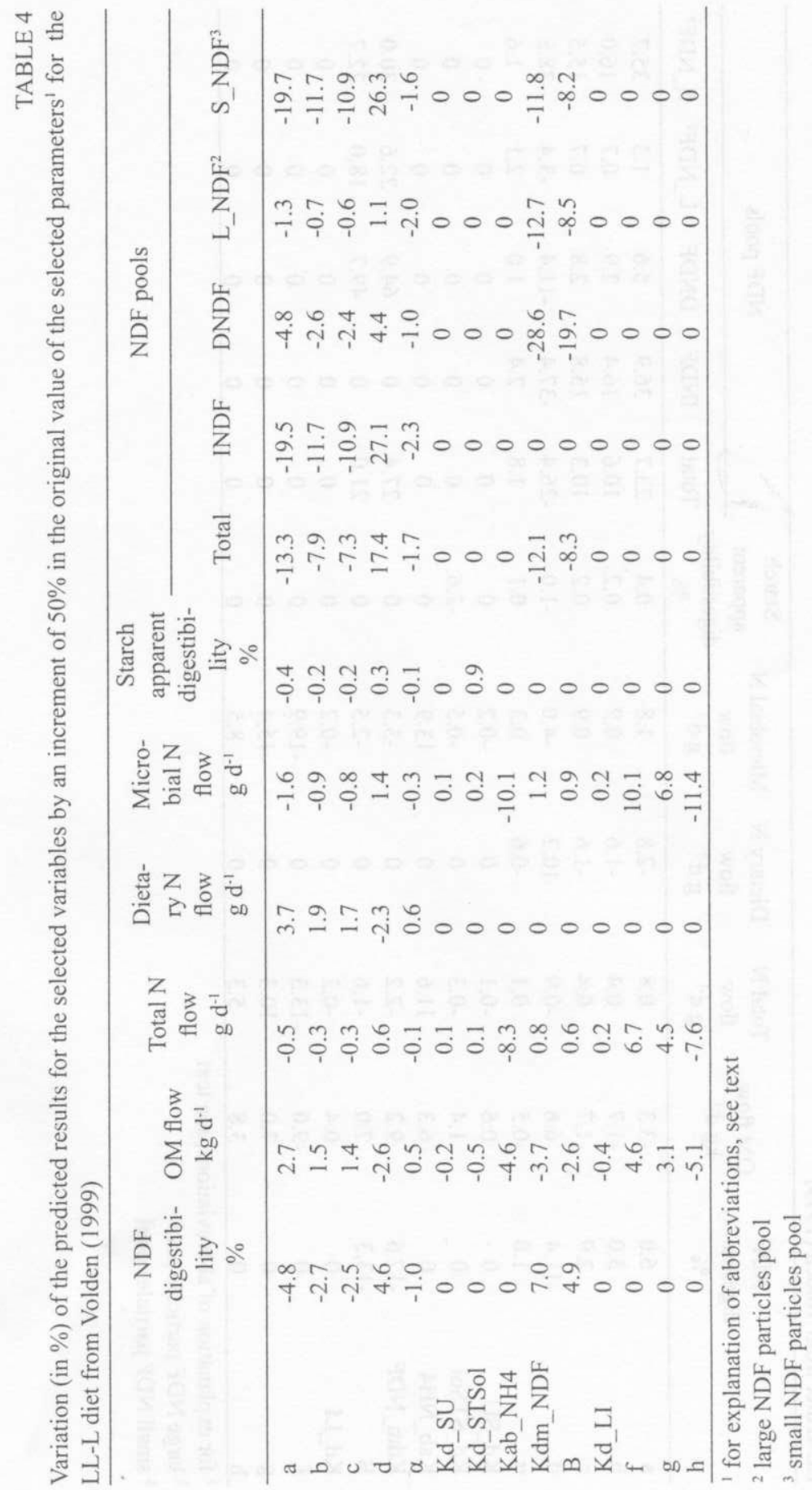




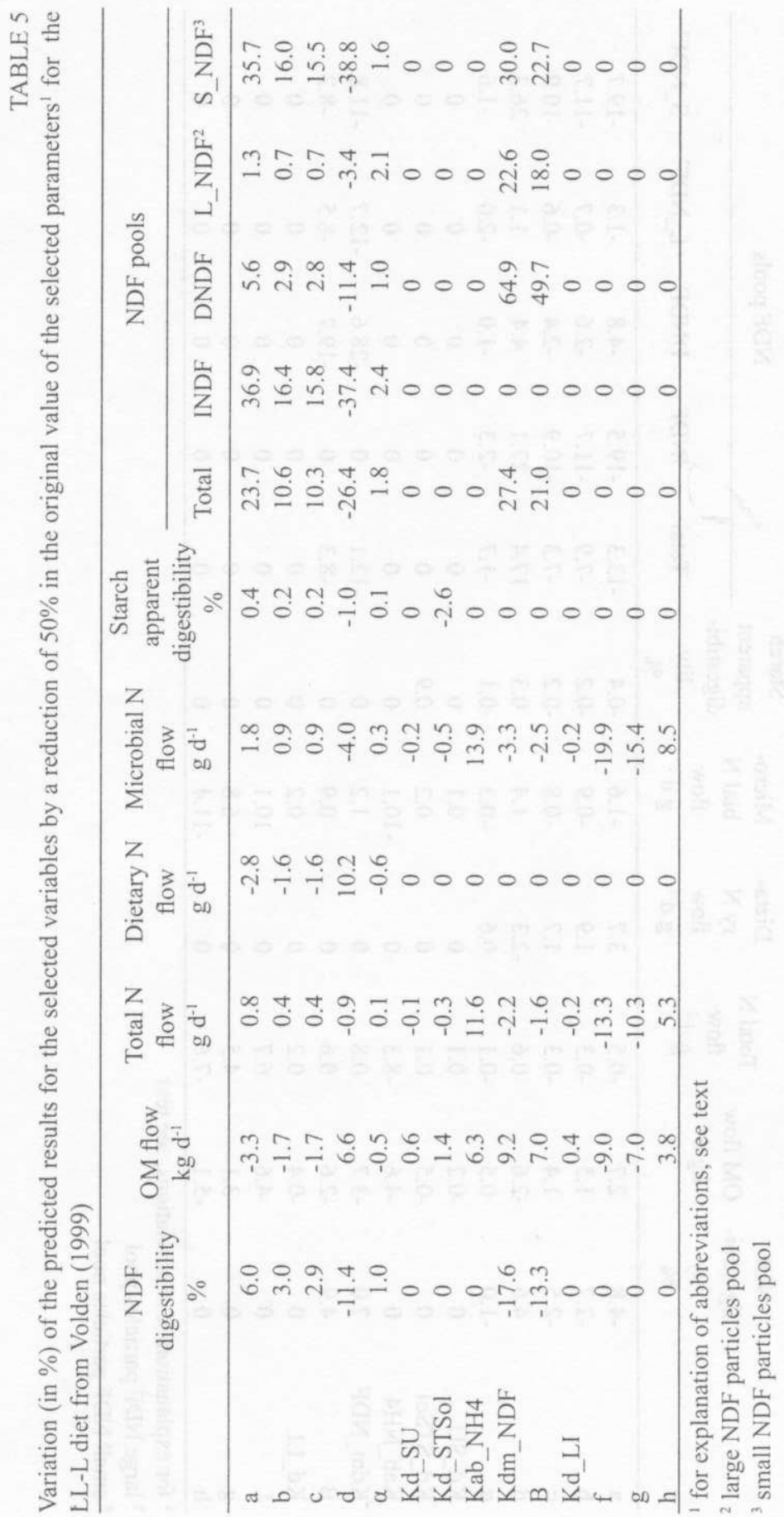


pools than the parameters mentioned above and these changes are more substantial with the $\mathrm{HH}-\mathrm{H}$ dict. The effects on NDF pool sizes of increasing the value of $\mathrm{Kdm}$ NDF or $\beta$ by $50 \%$ are approximately twice a high in absolute terms than a $50 \%$ decrease in these parameters.

\section{From comparative analysis}

In the comparative analysis, simulated values of NDF digestion and passage, apparent and true OM digestibility, starch digestibility, NDF pool ( $T_{-} N_{\text {NDF }}$ ) and $\mathrm{N}$ outflow from the rumen were compared to corresponding experimental values found by Overton et al. (1995), Crocker et al. (1998), Volden et al. (1999), Yang et al. (2000) and Lund (2002).

\section{NDF digestion and passage}

A broad range of NDF dietary concentration ( 22 to $62 \%$ of DM) and NDF intake ( 3.8 to $7.7 \mathrm{~kg} \mathrm{~d}^{-1}$ ) was used to test NDF passage and digestion. Observed and predicted values of these two variables are plotted in Figure 2 (a) and (b), respectively.

The model predicts NDF passage with a root MSPE of $288 \mathrm{~g} \mathrm{~d}^{-1}$, which is $9 \%$ of the observed mean. The prediction errors are not different when diets are grouped by type of supplemental grain or no supplement.

NDF digestion is predicted with an error of $8 \%$ of the observed mean and again no differences were found for diets supplemented or not. Decomposition of the error shows that ED provides almost all of the error for both NDF passage and NDF digestion ( 95 and $98 \%$, respectively).

NDF digestion was not affected by barley grain processing in the experiment carried out by Yang et al. (2000) and the model predicts the same result. Cattle do not efficiently digest whole barley and hence this must be processed before feeding. Appropriate processing of barley increases DMI, but does not affect NDF digestibility in the rumen.

A decrease in NDF digestion was observed in the experiment of Crocker et al. (1998), but the model predicts almost no change when steam-flaked maize replaces dry rolled maize grain. Theurer et al. (1999) reported that ruminal digestibility of NDF was decreased by an average of $16 \%$ when steam-flaked, with much greater proportion of digestible carbohydrates than dry-rolled maize, was fed to cows instead of cracked or rolled maize. A low crror of prediction for NDF passage and digestion, i.e. 8.4 and $5.6 \%$, respectively, is found when diets from Volden et al. (1999) are used as input to the model.

NDF digestibility predicted by the model is reduced due to supplementation as was found by Lund (2002) in an experiment with different forage source. Tamminga 
a) NDF passage to duodenum, $\mathrm{kg} / \mathrm{d}$

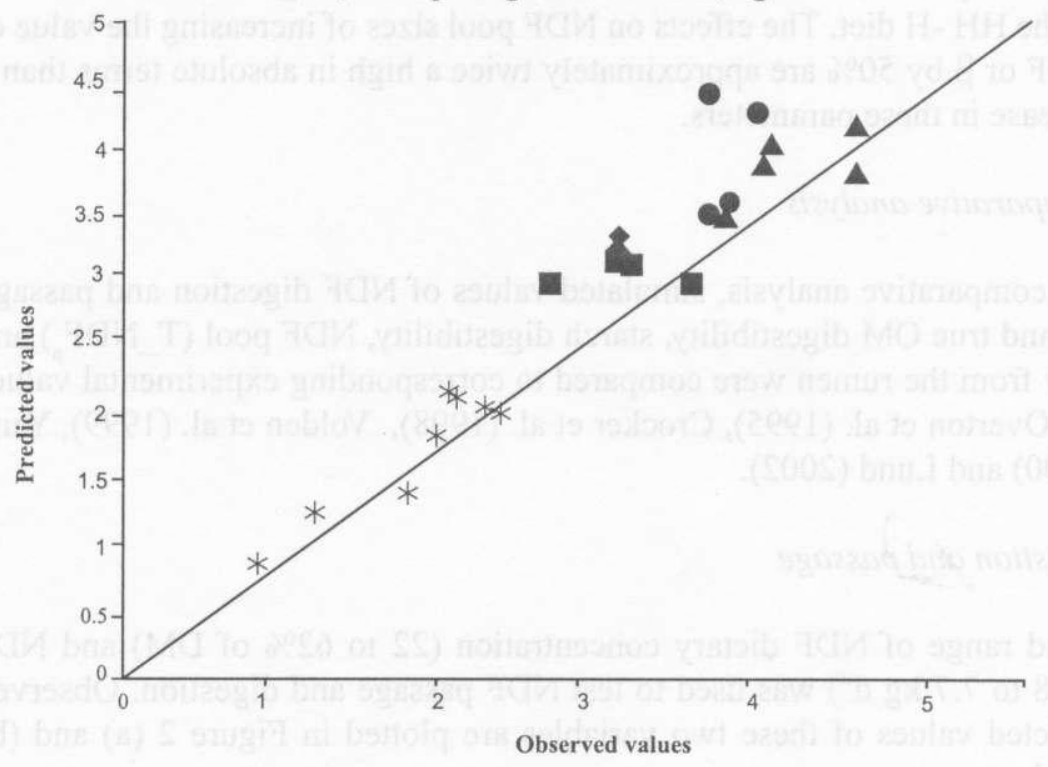

b) Ruminal NDF digestion, \%

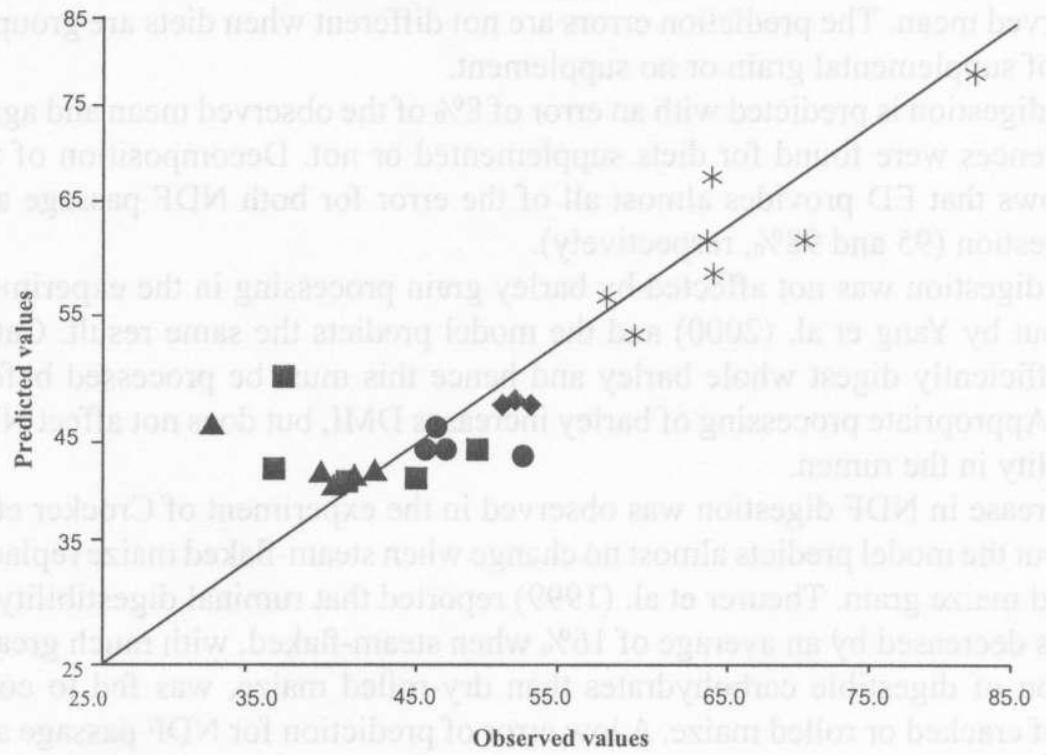

Figure 2. Comparison of observed and predicted values of (a) duodenal flows of NDF and (b) ruminal NDF digestion

- Yang et al. (2000); Crocker et al. (1998); $\boldsymbol{\Delta}$ Overton et al. (1995); Volden (1999); * Lund (2002) 
et al. (1990), Huhtanen and Jaakkola (1994) and Haddad and Grant (2000) reported the same negative effect on NDF digestibility. Prediction error for NDF passage and digestibility in diets with or without supplementation are 13,9.0, 8.6 and 4.5\% of the observed mean, respectively.

\section{OM apparent and true digestibility}

Figure $3(\mathrm{a}$ and $\mathrm{b}$ ) presents observed and predicted values of apparent and true $\mathrm{OM}$ digestibility, respectively. The apparent and true OM digestibilities in the rumen are overpredicted with an overall error of 25 and $23 \%$ of the observed mean, respectively. The main component of these errors is the bias proportion (ECT) with a 58 and $69 \%$ of the respective RMSPE.

Predicted values of apparent OM digestibility increase when barley replaces maize (from 39 to $47 \%$ ) in the diets tested by Overton et al. (1995). The same trend is observed in the corresponding experimental data (Overton et al., 1995) and this has also been reported previously in cattle (Kung et al., 1992).

In the experiments of Crocker et al. (1998), maize grain processing does not evince any change in apparent or true ruminal OM digestibility and the predicted values indicate a similar response, but with an overprediction of these variables and an error of prediction of 12 and $21 \%$, respectively. Joy et al. (1997) also found no differences in $\mathrm{OM}$ digestibility for diets containing dry-rolled or steam-flaked maize. Ruminal digestibility of OM was not affected by processing of barley grain in the diets 1 to 4 and the model predicted a similar behaviour for these diets (root MSPE of $9.8 \%$ for apparent and $11 \%$ for true OM digestibility).

Apparent and truc OM digestibility as mentioned before are overpredicted by the model, but these discrepancies are much higher when diets from Lund (2002) are simulated, especially for forages without supplementation. OM digestibilities, apparent and true, without the unsupplemented diets of Lund (2002) are predicted with errors of 17 and $16 \%$ of the observed mean, respectively.

Some of the observed values in this experiment are considerably low, e.g., the apparent OM digestibility for grass hay was estimated as $27.9 \%$. The method of duodenal flow determination was suggested as a potential source of error, if any, by the author (personal communication) for calculation of OM digestibility. The same reason was suggested by Archimide et al. (1997) as an important source of experimental variation in duodenal flow determination.

\section{$N$ metabolism}

Observed and predicted values of total $\mathrm{N}$, non-ammonium $\mathrm{N}$ (NAN), dietary $\mathrm{N}$ and microbial $\mathrm{N}$ passage from the rumen are shown in Figure $4(\mathrm{a}, \mathrm{b}, \mathrm{c}$ and $\mathrm{d}$, respectively). Total $\mathrm{N}$ and $\mathrm{NAN}$ flows are generally well predicted by the model 
a) Apparent $\mathrm{OM}$ digestibility, \%

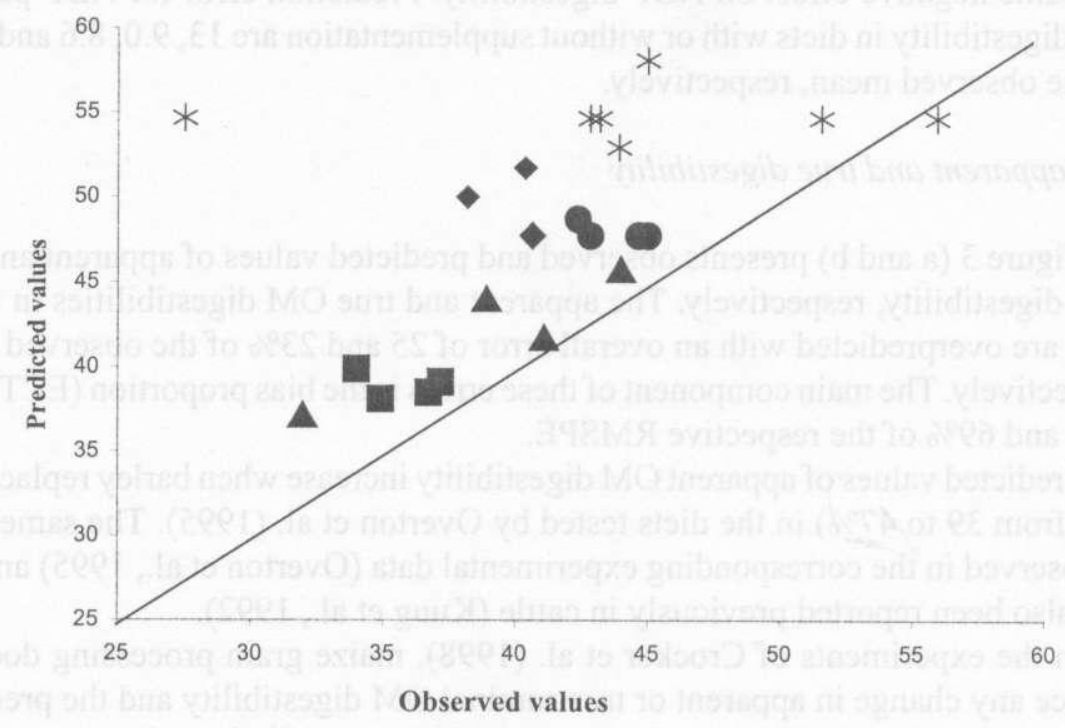

b) True OM digestibility, $\%$

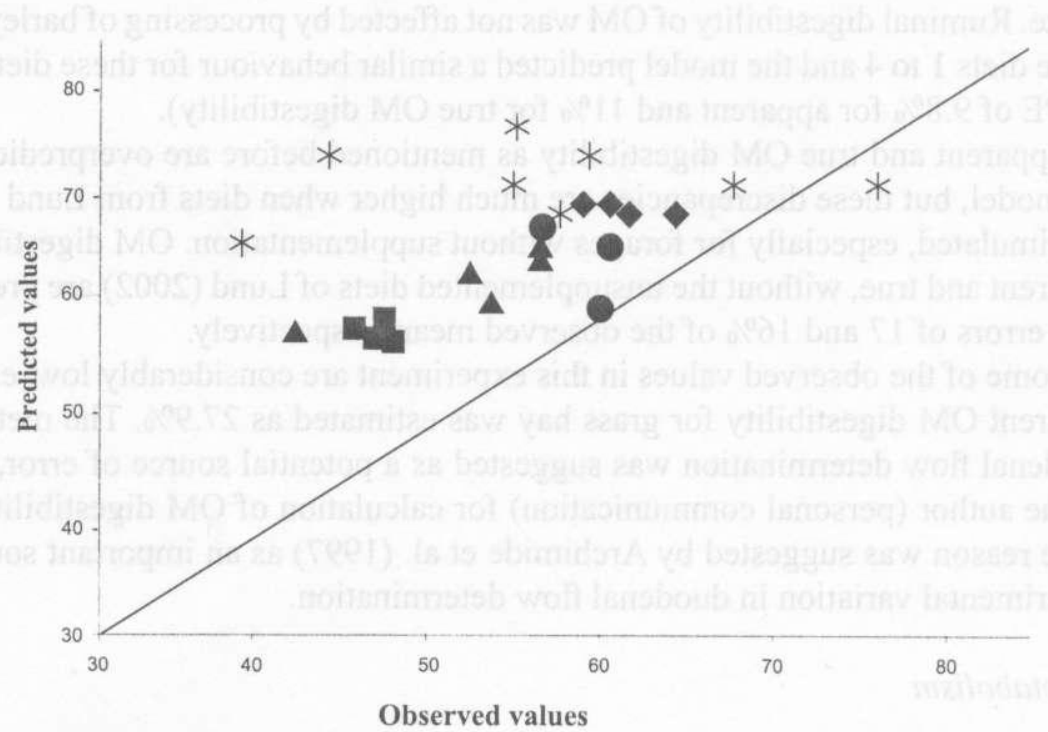

Figure 3. Comparison of observed and predicted values of (a) apparent and (b) true OM digestibility - Yang et al. (2000); Crocker et al. (1998); $\boldsymbol{\Delta}$ Overton et al. (1995); Volden (1999); * Lund (2002) 
with a root MSPE of 54 and $46 \mathrm{~g} \mathrm{~d}^{-1}$ corresponding to 12 and $9.3 \%$ of the observed mean, respectively. The random variation (ED) is 59 and $53 \%$ for total $N$ and NAN flow, respectively. The discrepancy of errors between total N and NAN outflow is because NAN outflow does not include data from Lund (2002) which caused higher error of prediction. There are almost no differences in the error of predictions when different sources of concentrates are used $(10.3 \%, 8.4 \%$ and $9.8 \%$ for diets using barley, maize grain or both as a supplement, respectively). As found by others (Neal et al., 1992; Dijkstra and France, 1996), the total NAN flow to the duodenum is predicted by this model with much higher accuracy than for its components, dietary, endogenous and microbial NAN.

Passage of dietary $\mathrm{N}$ is underestimated by the model with a root MSPE of $64 \mathrm{~g} \mathrm{~d}^{-1}(28 \%$ of the observed mean). Of this, the error due to overall bias (ECT) is $82 \%$. The highest error of prediction is reached with low intake diets (Lund, 2002; no supplementation). This underestimation of passage of dietary $\mathrm{N}$ will be solved, at least partially, by the inclusion of endogenous $\mathrm{N}$ secretion in the calculation of $\mathrm{N}$ entering to duodenum.

The present model predicts the outflow of microbial N (Figure 4d) with a root MSPE of $64 \mathrm{~g} \mathrm{~d}^{-1}$ (29\% of observed mean) and a bias and disturbance contribution of 48 and $39 \%$, respectively.

In agreement with published results (Robinson et al., 1986; Volden, 1999), the model predicts an increase in total microbial and dietary flows to the duodenum when the feeding level is increased.

The experimental data from Overton et al. (1995) were also used by Bateman et al. (2001) to test five different models with regard to prediction of crude protein passage to the duodenum. Overton et al. (1995) found that the passage of total $\mathrm{N}$, microbial $\mathrm{N}$ and dietary $\mathrm{N}$ was not significantly affected by substitution of maize starch with barley starch. Kung et al. (1992) also reported that the source of cereal starch (maize or barley) did not affect microbial $N$ outflow from the rumen. However, almost all models tested by Bateman et al. (2001) and also the present model predict a decreased flow of total and microbial $N$ to the duodenum when maize starch is replaced by barley starch. These results indicate that the present model and also those evaluated by Bateman et al. (2001) are less adequate in predicting the value of maize as a substrate for microbial growth compared with barley.

Dietary $\mathrm{N}$ passage values are underpredicted by all the models when barley grain replaces maize grain, but the values predicted by the present model are much closer to the experimental values than those predicted by the five model tested by Bateman et al. (2001). The root MSPE of dietary protein passage with these five models varies from 79 to $168 \mathrm{~g} \mathrm{~N} \mathrm{~d}^{-1}$ ( 30 to $63 \%$ of the mean) versus $58.4 \mathrm{~g} \mathrm{~N} \mathrm{~d}^{-1}$ ( $22 \%$ of the mean) with the present model.

The five models tested by Bateman et al. (2001) and also the present one prediet that the synthesis of microbial $\mathrm{N}$ is reduced and the degradation of feed pro- 

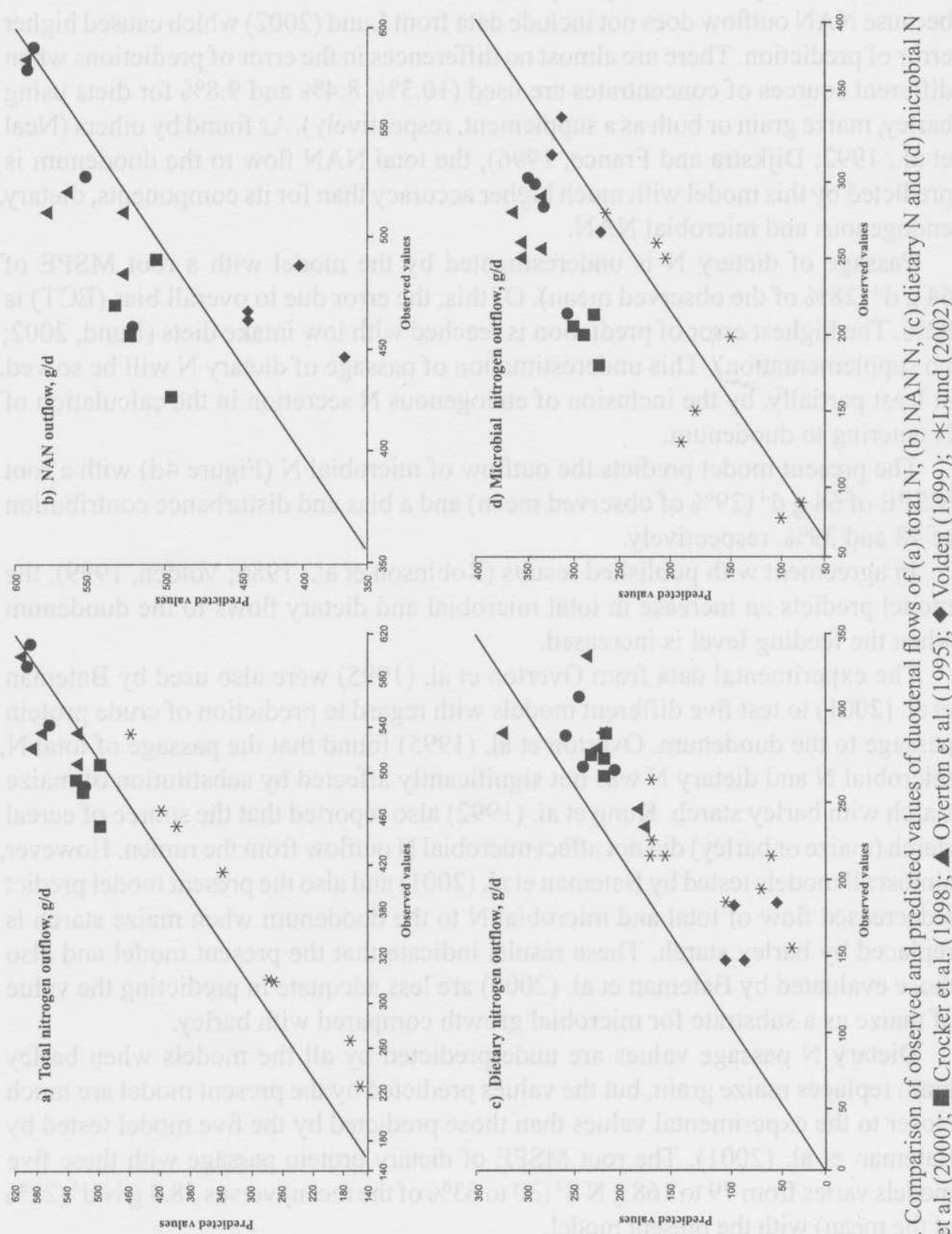

$\sum^{2}$

啇

쯔

๘ँ

दू ฮ

둥

ษ

突 3

을.

ํํㅇ

흘

त्व लं

$\nabla \pi$

\& 
tein is increased when barley replaces maize in the diets. This was not observed in the trial of Overton et al. (1995).

\section{Apparent ruminal starch digestibility}

The apparent ruminal starch digestibility is overestimated on average by $9 \%$ of the experimental values and the root MSPE is $25 \%$ of the mean (Table 6). The main contribution to this error is from the disturbance error (ED) contributing with $44 \%$.

TABLE 6 Comparison of observed and predicted values of apparent ruminal starch digestibility and ruminal NDF pool for the different diets used for external validation

\begin{tabular}{|c|c|c|c|c|}
\hline \multirow[t]{2}{*}{ Reference diet } & \multicolumn{2}{|c|}{$\begin{array}{c}\text { Starch digestibility } \\
\%\end{array}$} & \multicolumn{2}{|c|}{$\begin{array}{l}\text { NDF pool } \\
\mathrm{kg}\end{array}$} \\
\hline & observed & predicled & observed & predicted \\
\hline 1 & 61.0 & 86.6 & & \\
\hline 2 & 70.3 & 86.3 & & \\
\hline 3 & 70.5 & 86.3 & & \\
\hline 4 & 70.7 & 86.5 & & \\
\hline 5 & 24.8 & 63.1 & & \\
\hline 6 & 32.5 & 64.7 & & \\
\hline 7 & 37.8 & 67.0 & & \\
\hline 8 & 45.2 & 69.3 & & \\
\hline 9 & 41.9 & 63.7 & & \\
\hline 10 & 60.6 & 71.9 & & \\
\hline 11 & 60.9 & 77.5 & & \\
\hline 12 & 74.4 & 81.5 & & \\
\hline 13 & 74.4 & 83.1 & & \\
\hline 14 & 90.9 & 76.2 & 7.38 & 7.86 \\
\hline 15 & 89.5 & 82.4 & 7.25 & 7.92 \\
\hline 16 & 90.8 & 78.4 & 7.15 & 7.95 \\
\hline 17 & 89.4 & 83.9 & 6.99 & 7.77 \\
\hline 18 & & & 8.56 & 9.52 \\
\hline 19 & & & 5.04 & 4.77 \\
\hline 20 & & & 6.68 & 7.20 \\
\hline 21 & 94.3 & 83.5 & 7.69 & 7.93 \\
\hline 22 & 91.1 & 86.7 & 9.07 & 7.89 \\
\hline 23 & 85.1 & 81.6 & 5.59 & 4.64 \\
\hline 24 & 91.1 & 82.9 & 7.93 & 6.85 \\
\hline 25 & 89.4 & 87.1 & 7.59 & 6.02 \\
\hline RMSPE, \% & 25.3 & & 12.1 & \\
\hline
\end{tabular}

Root MSPE = root mean square of prediction crror (expressed as percentage of observed mean)

The lowest values in the prediction error correspond to diets with barley in the supplement $(14 \%)$ while the error of prediction is $19 \%$ for diets with both barley and maize. 
The model is wrong in predicting starch digestion with maize grain based diets, as the prediction error for these diets is $81 \%$. A complex interrelation among several factors determines the extent of starch digestion in the rumen. Among these factors can be mentioned source of dietary starch, diet composition, total feed intake, grain processing or chemical alterations. The apparent rumen digestibility of maize starch increases when dry-rolled maize is gradually replaced by steam- flaked maize (Crocker et al., 1998; Yu et al., 1998; Theurer et al., 1999). The present model also predicts this effect of maize processing although the level of digestibility is much too high when compared with the results of Crocker et al. (1998).

The higher ruminal starch digestibility due to processing of maize predicted by the model (Overton et al., 1995) is mainly due to three factors, i.e. increases in the water soluble starch fraction and in the fermentation rate constant of insoluble starch as well as an increase in the particle size of steam-flaked maize.

The model predicts that barley starch is more digestible in the rumen than maize starch in agreement with published results (Overton et al., 1995; Mills et al., 1999).

\section{Neutral detergent fibre pool}

Only data from Volden et al. (1999) and Lund (2002) were available to test NDF pool in the rumen. Experimental and predicted values for rumen NDF pool are shown in Table 6.

Total NDF rumen pool is predicted with a root MSPE of $0.87 \mathrm{~kg}$, which represents $12 \%$ of the observed mean. Decomposition of the MSPE attribute $62 \%$ to disturbance and $37 \%$ to regression proportion.

As found in the tested experiments, the NDF pool is variable between experiments and feeds. There are no big differences within the experiment of Volden et al. (1999) in the observed size of the NDF pool, and for this experiment the model overpredicts NDF pool by $9.7 \%$ of the observed mean. As was expected and also found in experiments and in litcrature, the NDF pool size decreases when the potential digestibility of NDF increases and increases when the NDF content of the forage is increased (Bosch, 1992).

For supplemented diets, from which the intake is higher compared to unsupplemented ones, the model predicts a slight reduction in the NDF pool. This means that the reduction in the digestion rate constant of NDF calculated in the model due to a higher proportion of easily fermentable carbohydrates is overrun by the increment in the passage rate of the solid fraction due to higher intake. The opposite tendency was found by Stensig et al. (1994) for diets with or without concentrates. Direct comparison of rumen pool sizes for supplemented or not supplemented forages in the experiments of Lund (2002), would give place to erroneous conclusions because the cows used in both experiments were in very different sta- 
ges of lactation. NDF load in rumen would be more related to the energy deficit of the animal, a measure that combines both animal and diet characteristics and not only to the chemical and/or physical composition of the diet.

\section{CONCLUSIONS}

The model described here responds adequately to changes in diet composition and level of intake as regards predictions of organic matter and NDF digestion or NDF pool in the rumen as well as total N and NAN passage from the rumen.

Considering the wide range of NDF content in the diets (from 22 to $62 \%$ of $\mathrm{DM}$ ), and intake level (from 8 to $23 \mathrm{~kg} \mathrm{DM} \mathrm{d}^{-1}$ ), the model behaved as expected with regard to NDF digestion at high and low feeding level, i.e. the digestibility decreases with increasing feed intake.

The predictions of starch digestibility and OM digestibility at least for some diets are not satisfactory and the model could be improved for these outputs.

As stated in the introduction, this model is to be incorporated into a more general model of feed intake regulation, and it is intended that most of the shortcomings reported in this paper will be mended in a future version of the model.

\section{REFERFNCES}

Ahvenjarvi S., Skiba B., Huthanen P., 2001. Effect of heterogeneous digesta chemical composition on the accuracy of measurements of fiber flow in dairy cows. J. Anim. Sci. 79, 1611-1620

Archimide H., Sauvant D., Schmidely P., 1997. Quantitative review of ruminal and total tract digestion of mixed diet organic matter and carbohydrates. Reprod. Nutr. Develop. 37, 173-189

Baldwin R.L., Thomlcy J.H.M., Beever D.E., 1987. Metabolism of the lactating cow. II. Digestive elements of a mechanistic model. J. Dairy Res. 54, 107-131

Bannink A., De Visser H., Dijkstra J., France J., 1997. Impact of diet-specific input paratneters on simulated rumen functions. J. Theor. Biol. 184, 371-384

Batajoo K.K., Shaver D.R., 1998. In situ dry matter, crude protein, and stareh degradabilities of selected grains and by-product feeds. Anim. Feed Sci. Tech. 71,165-176

Bateman H.G., Clark J.H., Patton R.A., Peel C.J., Schwabs C.G., 2001. Prediction of crude protein and amino acid passage to the duodenum of lactating cows by models compared with in vivo data. J. Dairy Sci. 84, 665-679

Beauchemin K.A., Farr B.l, Rode L.M., Schaalje G.B., 1994. Effects of alfalfa chop length and supplementary long hay on chewing and milk production of dairy cows. J. Dairy Sci. 77, 1326-1339

Beever D.E., 1993. Rumen function. In: J.M. Forbes, J. France (Editors). Quantitative Aspects of Ruminant Digestion and Metabolism. CAB lnternational, Wallingford (UK), pp.187-215

Bibby J., Toutenberg H., 1977. Prediction and lmproved Estimation in Lincar Models. Wiley, London 
Black J.L., Beever D.E., Faichney G.J., Howart B.R., Graham N.M., 1981. Simulation of the effects of rumen function on the flow of nutrients from the stomach of sheep, part 1 - Description of a computer program. Agr. Syst. 6, 195-219

Bosch M.W., Bruining M., 1995. Passage rate and total clearance rate from the rumen of cows fed on grass silages differing in cell-wall content. Brit. J. Nut. 73, 41-49

Bosch M.W., Lammers S.C.W., Bangma G.A.. Adrichem P.W., 1992. Influence of stage of maturity of grass silages on digestion processes in dairy cows. 2. Rumen contents, passages rates, distribution of rumen and faccal particles and mastication activities. Livest. Prod. Sci. 32, 265-281

Bruining M., Baker R., Van Bruchem J.P., Tamminga S., 1998. Rumen digesta kinetics in dairy cows fed grass, maize and alfalfa silage. 1. Comparison of conventional, steady-state and dynamic methods to estimate microbial degradation, comminution and passage of particles. Anim. Feed Sci. Tech. 73, 37-58

Bywater A.C., 1984. A generalised model of feed intake and digestion in lactating cows. Agr. Syst. $13,167-186$

Chilibroste P., Aguilar C., Garcia F., 1997. Nutritional evaluation of diets. Simulation model of digestion and passage of nutrients through the rumen reticulum. Anim. Feed Sci. Tech. $68,259-275$

Crocker L.M., DePcters B.J., Fadel J.G., Perez-Monti H., Taylor S.J., Wyckoff J.A., Zinn R.A., 1998. lnfluence of processed corn grain in diets of dairy cows on digestion of nutrients and milk composition. J. Dairy Sci. 81, 2394-2407

Danfær A., 1990. A dynamic model of nutrition, digestion and metabolism in lactating dairy cows. Ph.D. Thesis, Report 671, National Institute of Animal Science, Demnark

Dijkstra J., France J., 1996. A comparative evaluation of models of whole rumen function. Anı. Zootech. $45,175-192$

Dijkstra J., France J., Assis A.G., Neal H.D., Campos O.F., Aroeira L.J., 1996b. Simulation of digestion in cattle fed sugarcane, model development. J. Agr. Sci. 127, 231-246

Dijkstra J., Heather N., Beever D.B., France J., 1992. Simulation of nutrient digestion, absorption and outflow in the rumen, model description. J. Nutr. 122, 2239-2256

Faichney G.J., Poncet C., Boston R.C., 1989. Passage of internal and extemal markers of particulate matter through the rumen of sheep. Reprod. Nutr. Develop. 29, 325-337

Fisher D.S., 1996. Modelling ruminant feed intake with protein, chemostatic and distension feedback. J. Anim. Sci. $74,3076-3081$

Forbes J.M., 1980. A model of the short-term control of feeding in the ruminant. Effect of changing animal or feed characteristics. Appetite 1, 21-41

France J., Thornley J.H.M., 1984. Mathematical Models in Agriculture. Butterworth, London

France J., Thornley J.H.M., Beever D.E., 1982. A mathematical model of the rumen. J. Agr. Sci. 99 , 343-353

Galyean M.L., Wagner D. G., Owens F.N., 1981. Dry matter and starch disappearance of corn and sorghum as influenced by particle size processing. J. Dairy Sci. 64, 1804-1812

Haddad S.D., Grant R.J., 2000. Infiuence of nonfiber carbohydrate concentration on forage fiber digestion in vitro. Anim. Feed Sci. Tech. 86, 107-115

Hvelplund T., 1983. Kvantitative aspekter af fordøjelsen hos malkekoen. In: V. Østergaard, A. Neimann-Sørensen (Editors). Optimum Feeding of the Dairy Cow. Feed Composition, Feed Intake, Metabolism and Production. Rep. Nat. Inst. Anim. Sci., Copenhagen (Denmark)

Hvelplund T., 1986. The influence of the diet on nitrogen and amino acid content of mixed rumen bacteria. Acta Agr. Sci. 25,325-331

Hyer J.C., Oltjen J.W., Galycan M.L., 1991. Development of a model to predict forage intake by grazing cattle. J. Anim. Sci. 69,827-835 
Illius A.W., Gordon 1.J., 1991. Prediction of intake and digestion in ruminants by a model of rumen kinetics integrating animal size and plant characteristics. J. Agr. Sci. 1 16, 145-157

Joy M.T., DePeters E.J., Fadel J.G., Zinn R.A., 1997. Etfects of corn processing on the site and extent of digestion in lactating cows. J. Dairy Sci. 80, 2087-2097

Kung L., Tung R.S., Carmean B.R., 1992. Rumen fermentation and nutrient digestion in cattle fed dicts varying in forage and energy source. Anim. Feed Sci. Tech. 39, 1-9

Lescoat P., Sauvant D., 1995. Development of a mechanistic model for rumen digestion validated using the duodenal flux of amino acids. Reprod. Nutr. Develop. 35, 45-70

Lund P., 2002. 'The effect of forage type on passage kinetics and digestibility of fibre in dairy cows. Ph.D. Thesis. The Royal Veterinary and Agricultural University, Copenhagen (Denmark), pp. 169

Lykos T., Varga G.A., Casper D., 1997. Varying degradation rates of total nonstructural carbohydrates, effects on ruminal fermentation, blood metabolites, and milk production and composition in high producing Holstein cows. J. Dairy Sci, 80, 3341-3355

Mertens D.R., 1993. Kinetics of cell wall digestion and passage in ruminants. In: H.G. Jung, D.R. Buxton, R.D. Hatfield, J. Ralph (Editors). Forage Cell Wall Structure and Digestibility. Madison, Wisconsin (USA), pp. 535-570

Mertens D.R., 1997. Creating a system for meeting the fiber requirement of dairy cows. J. Dairy Sci. $80,1463-1481$

Mertens D.R., Ellis L.O., 1979. A dynamic model of fiber digestion and passage in the ruminant for evaluating forage quality. J. Anim. Sci. 49, 1085-1095

Mills J.A.N., France J., Dijkstra J., 1999. A review of starch digestion in the lactating dairy cow and proposals for a mechanistic model. 1. Dietary starch characterisation and ruminal starch digestion. J. Anim. Feed Sci. 8. 291-340

Møller J., Thøgersen R., Kjeldsen A.M., Weisbjerg M.R., Søegaard K., Hvelpiund T., Børsting C.F., 2000. Feedstuff Table Composition and Feeding Value of Feedstuffs for Cattle (English version). Report $N^{\circ}$ 9 1. J. Møl ler (Editor). The National Committee on Cattle Husbandry. Danish Institute of Animal Science, Foulum (Denmark)

Neal H.D., Dijkstra J., Gill M., 1992. Simulation of nutrient digestion, absorption and outflow in the rumen: Model evaluation. J. Nutr. 122, 2257-2272

Oosting S.J., Vlemmix P.J.M., Bruchem J.V., 1994. Effect of ammonia treatment of wheat straw with or without supplementation of potato protein on intake, digestion and kinetics of comminution, rumen degradation and passage in steers. Brit. J. Nut. 72, 147-165

Overton T.R., Cameron M.R., Elliot J.P., Clark J.R., Nclson D.R., 1995. Ruminal fermentation and passage of nutrients to the duodenum of lactating cows fed mixtures of corn and barley. J. Dairy Sci. 78, 1981-1998

Poppi D.P., Hendricksen R.E., Minson D.J., 1985. The relative resistance to escape of leaf and stem particles from the rumen of cattle and sheep. J. Agr. Sci. 105, 9-14

Poppi D.P., Minson D.J., Ternouth J.R., 1981. Studies of cattle and sheep eating leaf and stem fraction of grasses. 11l. The retention in the rumen of large feed particles. Aust. J. Agr. Res. 32, 123-137

Reichl J.R., Baldwin B.A., 1975. Rumen modelling: Rumen input-output models. J. Dairy Sci. 58, 879-889

Robinson P.R., Fadel J.G., Tamminga S., 1986. Evaluation of mathematical models to describe neutral detergent residue in terms of its susceptibility to degradation in the rumen. Anim. Feed Sci. Tech. 15, 249-271

Robles A.Y., Belyea R.L., Martz F.A., Weiss M.F., 1980. Effect of particle size upon digestible cell wall rate of in vitro digestion of alfalfa and orchardgrass forages. J. Anim. Sci. 51, 783-790 
Sauvant D., Baumont R., Faverdin P., 1996. Development of a mechanistic model of intake and chewing activitics of sheep. J. Anim. Sci. 74, 2785-2802

Shaver D.R., Nytes A.J., Satter L.D., Jorgensen N.A., 1988. Influence of feed intake, forage physical form and forage fiber content on particle size of masticated forage, ruminal digesta and feces of dairy cows. J. Dairy Sci. 71, 1567-1572

Storm E., Orskov E.R., 1983. The nutritive value of rumen micro-organisms in ruminants. 1. Largescale isolation and chentical composition of rumen micro-organisms. Brit. J. Nut. 50, 463-470

Tamminga S., Robinson P.H., Vogt M., Boer H., 1989. Rumen digesta kineties of ceil wall components in dairy cows. Anim. Feed Sci. Tech. 25, 89-98

Tamminga S., Van Vuuren A.M., Van Der Koelen C.J., Ketelaars 3.J.M.H., Van Der Togt P.L., 1990. Ruminal behaviour of structural carbohydrates, non-structural carbohydrates and crude protein from concentrate ingredients in dairy cows. Neth. J. Agr. Sci. 38, 513-526

Theil H., 1966. Applied Economic Forecasting, North Holl Publishing Company, Amsterdam

Theurer C.H., Huber T., Delgado-Elorduy A., Werley R., 1999. Summary of steam-Haking com or sorghum grain for lactating dairy cows. J. Dairy Sci. 82, 1950-1959

Ulyatt M.J., Dellow D.W., John A., Reid G.W., Waghorn G.C., 1986. Contribution of chewing during eating and rumination to the ciearance of digesta from the reliculorumen. In: L.P. Milligan. W. Grovum, A. Dobson (Editors). Control of Digestion and Metabolism in Ruminants. Englewood Cliffs, N.J., pp. 498-514

Volden H., 1999. Effects of level of feeding and ruminally tindegraded protein on ruminal bacterial protein synthesis, escape of dietary protein, intestinal amino acid profile, and performance of dairy cows. J. Anim. Sci. 77, 1905-1918

Volden H., Harstad O.M., 1998. Chemical composition of bacteria harvested from the rumen of dairy cows fed three diets differing in protein content and rumen protein degradability at two levels of leed intake. Acta Agr. Sci., Sect. A, Anim. Sci. 48,202-209

Volden H., Mydland L.T., Harstad O.M., 1999. Chemical composition of protozoal and bacterial fractions isolated from ruminal contents of dairy cows fed diets differing in nitrogen supplementation. Acta Agr. Sci., Sect. A, Anim. Sci. 49, 235-244

Weisbjerg M.R., Hvelplund T., Bibby B.M., 1998. Hydrolysis and fermentation rate of glucose, sucrose and lactose in the rumen. Acta Agric. Sci., Sect. A, Anim. Sci. 48, 12-18

Woodford, S.T., Murphy, M.R., 1988. Dietary alteration of particle breakdown and passage from the rumen in lactating dairy cows. J. Dairy Sci. 71, 687-696

Yang W.Z., Beauchemin K.A., Rode L.M., 2000. Effects of barley grain processing on extent of digestion and milk production of lactating dairy cows. J. Dairy Sci. 83, 554-568

Yu P., Huber J.T., Santos F.A.P., Simas J.M., Theurer C.B., 1998. Effects of ground, stean-flaked, and steam-rolled corn grains on performance of lactating cows. J. Dairy Sci. 81,777.783 


\section{STRESZCZENIE}

Dynamiczny symulacyjny model trawienia składników pokarmowych w żwaczu krów mlecznych

Opracowano mechanistyczny model trawienia składników pokarmowych w żwaczu krów mlecznych umożliwiający oszacowanie tempa trawienia oraz przepływu a także wielkości puli NDF przy określonym tempie pobierania suchej masy. W modelu uwzględniono różne frakcje pasz i ich chemiczne i fizyczne właściwości, a mianowicie 18 zmiennych parametrów w żwaczu reprezentujących węglowodany, związki azotu oraz drobnoustroje. Model odnosi się głównie do wskaźników określających stałe tempo przepływu drobnych cząstek i stałej tempa trawienia NDF. Model był sprawdzony dla diet różniących się znacznie ich pobraniem oraz składem. Tempo przechodzenia NDF i jego strawność, pula NDF, przepływ azotu całkowitego i nie-amonowego ze żwacza były dobrze oszacowane dla wszystkich badanych diet.

W przypadku niektórych diet, szczególnie tych które zawierały kukurydzę jako źródło skrobi, oszacowanie strawności substancji organicznej i skrobi, a także udział wypływającego azotu nieamonowego, pomiędzy azotem paszy a azotem drobnoustrojów, nie było zadowalające. 